\title{
Is classical mechanics based on Newton's Laws or Eulers analytical equations?
}

\author{
H.Iro \\ Institute for Theoretical Physics, \\ Johannes Kepler University, \\ Linz, Austria \\ Received December 26, 2004 \\ In an example I illustrate how my picture of physics is enriched due to my \\ frequent conversations with Reinhard Folk. The subject is: Who wrote down \\ the basic equations of motion of classical mechanics for the first time? (To \\ be sure, it was not Newton.)
}

Key words: history of science, classical mechanics

PACS: $01.65 .+9$

A volume dedicated to the anniversary birthday of a person usually contains some personal remarks. Often there is a short biography. Instead of doing so, I decided to write about a particular feature of my relationship with my colleague and friend Reinhard Folk, dating back nearly fourty years ago, when we studied physics together at the University of Vienna. Nearly every working day when he arrives at the institute he enters my room and we have a conversation either about some political issue or - more frequently - we talk about a subject in physics. In the following I will give a recent example. The topic originated from my activity at that time.

I was preparing a talk for the symposium "Der neue Blick ins All - von Peuerbach bis Newton" (The new perspective of the cosmos) in fall 2004. Starting mainly from Keplers work I intended to mention further "giants" of physics on whose shoulders Newton "could see further" and finally to give an outlook on the impact of Newton's laws. But these laws are in a verbal form, whereas the basic equations of motion of classical mechanics have the mathematical form of differential equations. So I asked myself: How are the basic equations of classical, Newtonian mechanics, related to Newton's laws? Who was the first in writing down the equations as we know them? Posing these questions also to Reinhard, he was first puzzled (like presumably many physicists will be) and then we recognized that it might be worth while to investigate about the mathematical, analytical origin of Newtonian mechanics. 
There is no doubt about Newton's laws: They are stated in the bible of physics, in his Principia [7]. The Principia are based "on the shoulders of the giants", in particular, besides Kepler and Galileo, on the shoulders of Huygens and Descartes (see e.g. [6]). So, for instance, Newton's first law can be found allready in Huygens "Horologium Oscillatorium" (see e.g. Speiser in [4]; this book has been brought to my attention by Reinhard) and his concept of space is an answer to Descartes concept of space as an extended body (see e.g. Böhme in [4]). Alas, Newton's laws are stated only in a verbal form, no single mathematical symbol or even a formula is given. Though he had allready his theory of fluxions at hand, Newton performed all his calculations in the Principia in a geometric (and not analytic) manner exploring the proportionality of the quantities involved; as an example I refer to Newton's proof of Proposition I (Theorem I, Book I) on central forces: "The areas, which revolving bodies describe by radii drawn to an immovable centre of force do lie in the same immovable planes, and are proportional to the times in which they are described" (For an interpretation of Newton's method in terms of the analytical approach I found Chandrasekhars excellent book extremely helpful). So, I searched in my books and found in Lagrange's "Analytical Mechanics" that the analytical approach is due to Euler. In his first book on mechanics [2] he decomposed the forces, including the inertial force $m \mathrm{~d} \mathbf{v} / \mathrm{d} t$ (written in modern notation), in components tangential and normal to the instantaneous direction of motion. The method we use today, i.e. projecting the forces onto fixed axes is due to MacLaurin ("A Treatise of fluxions" (1742)); also Mach is of the same opinion. In the meantime, Reinhard looking into his private library - he is a book addict, in particular he is fond of old books - found a statement by Simonyi that in 1750 Euler was the first who used the analytical approach in a contribution to the Mémoirs de l'Académie des Sciences de Berlin [8]. This reference we could not verify. But definitely in his so-called second book on mechanics [3] on the motion of solid bodies Euler used already the representation in terms of a fixed system of axes. Mechanics as we understand today is based on this form of the equations of motion. They give rise to all the achievements of physicists, mathematicians, technical scientists, and astronomers in classical mechanics. Still, there remains the question whether it is possible to deduce these results also within Newton's geometrical approach based on his laws, that, as is sometimes claimed, are more comprehensive than the analytical equations.

Another question we are considering right now is the attitude amongst some practitioners of continuum mechanics (e.g. C. Truesdell, I. Szabo), claiming that point mechanics is not sufficient to explain the mechanical laws for a continuum system. Their claim is partly based on - to put it mildly - strange arguments against the concept of a point mass as used in various forms in many textbooks on mechanics. What is more, these persons seem to be not aware of Newton's concept of a body consisting of particles (see e.g. Principia Book I, Proposition LXXXVI: "If the forces of the particles of which an attractive body is composed ...") and Eulers statement in the preface of his book on mechanics from 1735, that the motion of bodies of finite size cannot be explained, if one did not investigate in advance the motion of the points, of which the bodies are imagined to be built. Both, Newton and Euler, are 
also amongst their main sources and alleged supporters in their argumentation. As a consequence we are starting right now a discussion with a scientist at the institute of technical mechanics about the derivation of the basic equations of continuum mechanics.

Reinhard, I wish you also in the future many books to find and for my part a continuing atmosphere of discussions and conversations.

\title{
References
}

1. Chandrasekhar S. Newton's Principia for the Common Reader. Clarendon Press, Oxford, 1995.

2. Euler L. Mechanica sive Motus Scientia Analytice exposita. 1736. Mechanik, 2 vols, German transl. by Ph. Wolfers, C.A. Koch, Greifswald, 1848 and 1850.

3. Euler L. Theoria Motus Corporum Solidorum seu Rigidorum. 1765. German transl. by Ph. Wolfers; C.A. Koch, Greifswald, 1853.

4. Hutter K. Die Anfänge der Mechanik. Springer, Berlin, 1989.

5. Lagrange J.L. Mécanique Analytique. 1788. Analytische Mechanik, German transl. by H. Servus. Springer, Berlin, 1887.

6. MacLaurin C. An Account of Sir Isaac Newton's Philosophical Discoveries. London, 1748.

7. Newton I. Philosophiae Naturalis Principia Mathematica. 1686. The Principia, English transl. by A. Motte, Prometheus Books, New York, 1995.

8. Simonyi K. Kulturgeschichte der Physik. Harri Deutsch, Thun/Frankfurt, 1995.

\section{Класична механіка базується на законах Ньютона чи на аналітичних рівняннях Ойлера?}

\author{
Г.ІІро \\ Інститут теоретичної фізики, \\ Університет Йогана Кеплера, \\ Лінц, Австрія \\ Отримано 26 грудня 2004 р.
}

На одному прикладі я ілюструю, як збагатилась моя картина фізики завдяки частим розмовам з Райнгардом Фольком. Предметом є: хто вперше записав основні рівняння руху класичної механіки? (Без сумніву, це був не Ньютон).

Ключові слова: історія науки, класична механіка

PACS: $01.65 .+9$ 
